\title{
Peranan Komunikasi Antarpersona Orang Tua terhadap Kemampuan Penyesuaian Sosial Siswa di Sekolah
}

\author{
Agus Sofyandi Kahfi \\ ABSTRACT \\ Many factors contribute student's failure in social adaptation. Parents busy schedule, \\ the lack of quality in communication and interaction, also interpersonal communication failure \\ are exemplars of such factors. In order to improve student's ability to successfully \\ adapt themselves in social spaces, a strong interpersonal communication was needed. DeVito \\ outlined some characteristics of interpersonal communication: openness, empathy, \\ supportiveness, positiveness, and equality. By applying the principles of interpersonal \\ communication, parents could help their children socialization in school. In turn, it could help \\ their children to gain better academic achievements.
}

Kata kunci: komunikasi antarpersona, adaptasi social, keterbukaan, kesetaraan, empati

\section{Pengantar}

Dalam upaya mencapai tujuan pendidikan, semua lembaga pendidikan (sekolah), telah membuat peraturan-peraturan yang harus ditaati para siswanya. Peraturan yang disusun biasanya berkaitan dengan hal-hal yang berhubungan dengan kegiatan intrakurikuler, ekstrakurikuler, dan aturan-aturan yang berhubungan dengan etika berelasi dengan semua pihak yang ada di sekolah.

Kenyataan yang ditemukan, masih banyak para siswa yang tidak mampu menaati peraturanperaturan yang telah ditentukan pihak sekolah tersebut. Misalnya, masih banyak siswa yang sering tidak hadir di sekolah beberapa hari lamanya (membolos), kabur di jam sekolah, tidak menunjukkan motivasi belajar yang kuat, tidak menggunakan seragam sesuai aturan, menggunakan aksesoris berlebihan. Selain itu, masih banyak siswa yang tidak mampu menghormati otoritas sekolah (kepala sekolah dan para guru) dan mengganggu teman lain, sehingga tidak jarang menimmbulkan perkelahian di antara mereka. Kondisi ini menggambarkan bahwa masih banyak siswa yang mengalami kegagalan untuk melakukan penyesuaian di lingkungan sekolah.

Jika ditelusuri lebih jauh, banyaknya siswa yang mengalami kegagalan dalam melakukan penyesuaian sosial di sekolah, menyatakan bahwa orang tua mereka adalah oarang tua yang sibuk berusaha dan bekerja untuk memenuhi kebutuhan ekonomi keluarga, sehingga orang tua mereka 
kurang mampu memberikan perhatian dan empati terhadap mereka, kurang peduli dengan prestasi belajar mereka, dan kurang terbuka untuk mendiskusikan masalah-masalah pribadi dan sekolah mereka. Dengan kata lain, orang tua kurang mampu menciptakan komunikasi antarpersona yang efektif dengan anak meraka.

Kegagalan orang tua dalam menciptakan komunikasi antarpersona yang efektif dengan anak mereka, tidak lepas dari kesibukan orang tua untuk memenuhi kebutuhan ekonomi keluarga dan tuntutan dari pekerjaan saat ini. Banyak orang tua yang pergi untuk berusaha dan bekerja sejak pagi dan baru pulang ke rumah setelah malam tiba. Bahkan, tidak sedikit dalam satu keluarga kedua orang tua harus harus pergi berusaha dan bekerja dengan mengikuti tuntutan waktu seperti di atas.

Usaha dan kerja orang tua sejak pagi sampai malam akan mengantarkan orang tua untuk bisa memenuhi kebutuhan ekonomi keluarga, bahkan mampu menyekolahkan anak-anak mereka ke jenjang pendidikan yang lebih tinggi. Tetapi, tidak bisa dipungkiri bahwa akibat lainnya adalah banyak orang tua yang tidak bisa memberikan perhatian penuh terhadap perkembangan anakanak mereka di sekolah.

Kondisi di atas bisa terlihat dengan ketidak tahuan orang tua tentang ketidakhadiran anak mereka di sekolah beberapa hari lamanya, kebiasaan anak-anak mereka kabur di jam sekolah, tidak menggunakan seragam sesuai aturan, menggunakan aksesoris berlebihan, dan lain sebagainya. Selain itu, banyak orang tua yang kurang memiliki kesempatan untuk berpartisipasi pada kegiatan-kegiatan yang diselenggarakan pihak sekolah dalam upaya mendiskusikan persoalan yang dihadapi para siswa, baik yang berhubungan dengan pelanggaran terhadap tugastugas yang diberikan para guru ataupun pelanggaran terhadap aturan-aturan sekolah.

\section{Komunikasi Antarpersona}

Dalam pandangan DeVito, komunikasi orang tua-anak, termasuk dalam komunikasi interpersonal. DeVito mengartikan komunikasi antarpersona sebagai "proses pengiriman pesanpesan antara dua orang atau sekelompok kecil orang, dengan beberapa efek dan beberapa umpan balik seketika" (DeVito, 1989:4).

Dari definisi di atas, DeVito mengungkapkan ciri-ciri komunikasi antarpersona sebagai berikut:

(1) Adanya pesan yang disampaikan oleh si pengirim kepada si penerima, baik pesan verbal maupun nonverbal. Menurutnya, proses ini tidak harus berlangsung secara tatap muka, tetapi yang perlu diperhatikan adalah sejauh mana efek dan umpan balik bisa terjadi,

(2) Adanya individu yang terlibat dalam komunikasi antarpersona, paling sedikit dua orang, yaitu sumber dan penerima, bahkan mungkin melibatkan sekelompok kecil individu,

(3) Adanya penerimaan pesan yang disampaikan oleh pihak lain,

(4) Adanya efek dari komunikasi, yaitu adanya pengaruh tertentu dari si penerima. Efek ini bisa berupa kesetujuan total atau ketidaksetujuan total,

(5) Adanya umpan balik, yaitu pesan yang dikirim kembali oleh si penerima baik secara sengaja maupun tidak sengaja.

Dalam bahasan selanjutnya, DeVito mengungkapkan lima ciri komunikasi antarpersona yang efektif, yaitu:

(1) Opennes (keterbukaan)

Menurut DeVito (1989:96), kualitas keterbukaan pada komunikasi antarpribadi, paling tidak, ditunjukkan oleh tiga karakteristik yaitu:

(a) Kesediaan untuk saling membuka diri, baik pada diri komunikan maupun komunikator, sehingga terjadi pertukaran informasi.

(b) Kesediaan komunikator untuk bereaksi secara jujur terhadap stimulus yang dihadapi. Dapat ditunjukkan dengan memberikan respons secara spontan dengan memakai dalih dalam berkomunikasi dan menanggapi orang lain. 
(c) Kesediaan untuk bertanggung jawab terhadap hal-hal yang dirasakan dan dipikirkan dan tidak berusaha menyalahkan orang lain.

(2) Empaty (empati)

DeVito (1989:101) menjelaskan bahwa empati terhadap seseorang berarti dapat merasakan apa yang dirasakan, dapat mengalami apa yang dialami orang lain tersebut tanpa kehilangan identitas diri. Ditegaskan bahwa dengan empati, seseorang memroyeksikan pikiran dan perasaan ke dalam objek pengalamannya dan dengan empati kita melihat bagaimana orang lain melihat dan merasakan seperti orang lain merasakannya.

(3) Supportiveness (dukungan)

Supportiveness atau kesuportifan dapat diartikan sebagai sikap untuk memberi dukungan kepada orang lain yang membutuhkan. Pemberian dukungan dapat berwujud kata-kata yang menyenangkan, persetujuan, mengurangi ketegangan, atau menentramkan orang lain. Gibb (DeVito, 1989:100) mengatakan bahwa sikap suportif ditunjukkan dan ditekankan pada dua kecenderungan, yaitu:

(a) Menyampaikan persepsi dan perasaan kita kepada komunikan secara deskriptif tanpa mengadakan penilaian. Beberapa ciri dan komunikasi yang bersifat deskriptif, antara lain, dalam mengucapkan kata-kata, lebih sering menggunakan kata kerja bukan kata sifat, berorientasi pada masalah yang bertujuan untuk memecahkan masalah, bersifat spontan, dan tidak mempunyai motif-motif yang terpendam.

(b) Bersikap profesional dan bukan dogmatis. Sikap profesional adalah kesediaan untuk meninjau kembali pendapat kita. Sikap yang terbuka dan kesediaan mendengarkan pandangan yang berbeda dan lawan bicaranya.

(4) Positiveness (sikap positif)

Sikap positif ini, menurut DeVito (1978:100101), dapat ditunjukkan dengan memberikan penghargaan yang jujur pada orang lain, baik melalui tingkah laku verbal maupun nonverbal.

(5) Equality (kesamaan)

Kesamaan dalam sikap memperlakukan orang lain secara horizontal dan demokratis. Dengan kesamaan berarti tidak mengandung; sikap menggurui dalam berkomunikasi karena masing-masing mempunyai (kedudukan yang seimbang/sejajar).

\section{Penyesuaian Sosial di Sekolah}

Menurut Schneider, penyesuaian sosial merupakan "kemampuan untuk bereaksi secara efektif terhadap kenyataan yang ada di lingkungannya, sehingga seorang mampu untuk memenuhi tuntutan sosial dengan cara yang dapat diterima dan memuaskan bagi dirinya maupun lingkungannya." Jika individu ingin mencapai kematangan penyesuaian sosial, maka ia harus mampu menciptakan suatu relasi yang sehat dengan orang lain serta menghargai nilai-nilai yang berlaku di masyarakat.

Sehubungan dengan pengertian di atas, Schneider menyatakan bahwa seorang siswa yang mampu menyesuaikan diri di lingkungan sekolah, akan memeiliki karakteristik:

(1) Mau menerima dan menghormati otoritas sekolah yang meliputi kesediaan siswa untuk menaati peraturan sekolah, pimpinan sekolah dan guru, dengan sukarela perasaan enggan atau terpaksa;

(2) Tertarik dan mau berpartisipasi pada aktivitas sekolah, mau melibatkan diri pada kegiatankegiatan yang ada di lingkungan sekolah serta adanya keinginan untuk melibatkan diri dalam aktivitas tersebut.

(3) Mau menjalin relasi yang baik dengan teman sekolah, guru dan unsur-unsur sekolah, tanpa diwarnai perasaan yang kurang baik seperti kebencian, iri hati, dan penolakan.

(4) Mampu menerima tanggung jawab yang diberikan sekolah, dapat bersikap dan bertingkah laku sesuai dengan perannya sebagai siswa, serta mampu menjaga nama baik sekolah. 
Selanjutnya Scheneider (1964:122) menyatakan bahwa baik buruknya kemampuan penyesuaian sosial di sekolah ini, akan dipengaruhi oleh variabel internal dan eksternal siswa. Faktorfaktor internal meliputi: kondisi fisik, pengaruh keturunan, konstitusi fisik, keadaan sehat maupun keadaan sakit; kematangan intelektual, emosi, sosial, moral siswa; Faktor psikologis meliputi proses belajar, pendidikan dan penerimaan diri. Faktor-faktor eksternal meliputi: kondisi lingkungan rumah dan keluarga serta faktor kebudayaan termasuk adat istiadat dan agama.

Menurut Scheneider, faktor rumah maupun keluarga merupakan faktor yang penting dari sekian banyak faktor yang memengaruhi penyesuaian sosial, karena keluarga merupakan satuan kelompok sosial yang terkecil dan interaksi sosial pertama yang diperoleh individu adalah dalam keluarga yang kemudian akan dikembangkan di masyarakat.

\section{Analisis}

Setiap siswa yang masuk ke lingkungan sekolah mempunyai pelbagai tugas yang harus dipenuhinya. Salah satu tugas siswa di sekolah adalah mencapai perilaku sosial dan bertanggung jawab. Perilaku sosial siswa di lingkungan sekolah ini berhubungan erat dengan kemampuan penyesuaian sosial siswa di lingkungan sekolah.

Penyesuaian sosial di lingkungan sekolah, berhubungan dengan kemampuan penyesuaian diri di lingkungan keluarga. Kegagalan remaja dalam melakukan penyesuaian diri di Iingkungan keluarga akan memengaruhi kemampuan siswa dalam penyesuaian dirinya di Iingkungan sekolah. Jika penyesuaian di lingkungan keluarga baik, maka baik pula penyesuaian sosial di lingkungan sekolah. Karena, menurut Schneider, faktor yang akan memberikan kontribusi besar terhadap kemampuan penyesuaian diri di Iingkungan sekolah, salah satunya adalah kondisi lingkungan rumah atau lingkungan keluarga.

Agar siswa dapat berhasil dalam menyesuaikan diri di lingkungan keluarga, maka ia harus mempunyai hubungan yang baik dengan anggota keluarganya, terutama dengan kedua orang tuanya.
Karena di dalam rumahlah para siswa melakukan hubungan timbal balik dengan rang tuanya, dalam hubungan timbal balik ini terjadi komunikasi antara orang tua dengan anak.

Hubungan yang baik dengan anggota keluarga, sangat dipengaruhi oleh efektivitas komunikasi antara orang tua dengan anak. Menurut DeVito, komunikasi yang efektif antara remaja dan orang tua ditandai dengan adanya pemahaman remaja tentang keterbukaan, rasa empati, dukungan, sikap positif dan perasaan sama dari orang tua.

Adanya keterbukaan orang tua menunjukkan adanya kesediaan orang tua untuk membuka diri terhadap anak, kesediaan orang tua untuk bereaksi secara jujur terhadap anak dan kesediaan untuk bertanggung jawab dan tidak menyalahkan anak. Keterbukaan bukan berarti bahwa setiap orang tua harus selalu menyamakan diri dengan anak dalam segala bidang. Pada dasarnya, setiap orang tua harus mempunyai sistem nilai, standar, moral, dan etika, sikap, keyakinan dan kepercayaan, serta pandangan sendiri. Namun, tidak harus tertutup untuk mendengarkan dan mencernna masukan dari anak. Orang tua ataupun anak, harus bersedia untuk menerima masukan dari orang lain dan mengubah diri ke arah yang lebih positif. Adanya keterbukaan berkomunikasi dalam keluarga memungkinkan setiap individu dapat berbicara dengan keluarga lainnya dengan status yang sederajat. Masing-masing anggota keluarga dapat saling berbicara, berhubungan secara akrab, sehingga terpenuhi kebutuhan antarpribadi.

Empati, yaitu dapat merasakan dan dapat mengalami apa yang dirasakan dan dialami oleh anak. Dengan empati, Orang tua mendengarkan dengan sungguh-sungguh dan bijaksana terhadap apa yang ingin dikatakan anak, sehingga akan menyebablan anak merasa dimengerti oleh orang tuanya. Kemampuan berempati dari orang tua, akan menambah sikap percaya dan perasaan dimengerti anak pada orang tua yang ahirnya akan meningkatkan komunikasi efektif antara orag tua dengan anak.

Supportiveness atau dukungan yang diberikan orang tua, menggambarkan bahwa dalam menyampaikan persepsi dan perasaan kepada anak, 
orang tua berusaha menyampaikannnya tanpa penilaian dan bersikap profesional. Dalam hal ini, tercermin kesediaan orang tua untuk meninjau kembali pendapat mereka dan kesediaan mereka untuk mendengarkan pandangan yang berbeda dari anak.

Selanjutnya, positiveness atau sikap positif, menggambarkan kesediaan orang tua untuk memberikan penghargaan yang jujur pada anak melalui tingkah laku verbal atau nonverbal. Tingkah laku verbal dengan menggunakan bahasa yang tegas dan tidak ragu-ragu. Tingkah laku nonverbal misalnya dengan senyuman, anggukan, usapan tangan, dan tepukan di bahu. Sikap positif akan memperlihatkan perhatian orang tua terhadap anak sebagai manusia secara utuh dan mendorong perkembangan potensi anak yang cenderung untuk mengembangkan keberanian serta kepercayaan diri.

Adapun equality atau kesamaan, menggambarkan ada kesediaan orang tua untuk memperlakukan anak secara horizontal dan demokratis, karena kedua belah pihak mempunyai kedudukan yang seimbang atau sama. DeVito (1989:346) menegaskan bahwa dalam prinsip kesamaan, masing-masing pihak harus bersedia menjadi pembicara dan pendengar. Bersedia mengungkapkan apa yang dirasakannya, tetapi juga bersedia mendengar apa yang dikatakan oleh orang lain. Kesamaan ini juga diperlukan apabila terjadi konflik atau masalah orang tua-anak. Kesamaan dalam nemecahkan konflik, berarti penyelesaian harus dapat diterima oleh kedua belah pihak dan memuaskan bagi keduanya. Kesamaan juga menimbulkan perasaan yang dipercaya oleh orang tua, tidak dianggap sebagai anak kecil oleh orang tua, karena anak ikut ambil bagian dalam memecahan masalah dan pengambilan keputusan.

Jika komunikasi orang tua dengan anak efektif, maka anak akan mempunyai persepsi yang positif terhadap komunikasi orang tuanya. persepsi yang positif ini merupakan penilaian yang baik dan seorang anak terhadap komunikasi yang dilakukan oleh orang tuanya. Jika persepsi anak terhadap komunikasi orang tuanya positif, maka akan memudahkan bagi anak untuk dapat menyesuaikan diri dengan baik di lingkungan keluarganya. Jika siswa berhasil dalam menyesuaikan diri di lingkungan keluarganya kemungkinan ia akan dapat menyesuaikan diri dengan baik di lingkungan sekolah. Demikian sebaliknya, jika komunikasi orang dengan anak tidak efektif, maka anak akan memberikan persepsi yang negatif terhadap komunikasi orang tuanya, yaitu penilaian yang buruk terhadap komunikasi yang dilakukan oleh orang tuanya dan penyesuaian diri remaja di lingkungan keluarga kemungkinan akan menjadi buruk. Jika ini terjadi, maka penyesuaian sosial remaja di sekolah pun kemungkinan besar akan menjadi buruk.

\section{Kesimpulan}

Orang tua memegang peranan besar dalam menunjang keberhasilan anak mereka di sekolah, salah satu kunci keberhasilan siswa di sekolah diawali dengan keberhasilan mereka untuk melakukan penyesuaian sosial di lingkungan sekolah. Salah satu faktor utama yang dapat mengantarkan siswa mampu menyesuaikan diri dengan aturan-aturan sekolah adalah keberhasilan orang tua membina komunikasi efektif dengan mereka.

Komunikasi efektif, tidak ditentukan oleh kuantitas pertemuan orang tua dengan anak, tetapi sangat ditentukan oleh kualitas dari pertemuan tersebut. Dalam hal ini, sejauh mana orang tua mampu menciptakan komunikasi yang terbuka, menunjukkan empati terhadap persoalan anak, memberikan dukungan, sikap yang positif, dan menggunakan prinsip kesamaan dalam komunikasi. Dengan kata lain, jika orang tua mengharapkan keberhasilan anak mereka di sekolah, maka sesibuk apa pun, maka mereka harus berusaha mengembangkan komunikasi efektif dengan anakanak mereka.

\section{Daftar Pustaka}

DeVito, Joseph A., The Interpersonal Communication Book, 1089, Fifth Edition, New York: Harper And Row Publisher. 
Santrock, John W., Life Span Development, Edisi Kelima, Jakarta: Erlangga.
Scheneider, A. Alexander, 1954, Personal Adjusment And Mental Healt, New Delhi: Tata Mc. Graw-Hill Publishing Comapany Limited. 